\title{
Examining the Intellectual Capital Impact on the Profit Efficiency in Automobile and Parts Manufacturing Industry of Tehran Stock Exchange
}

\author{
Safdar Alipour, ${ }^{1,}$, Majid Gorgizadeh ${ }^{2}$ \\ ${ }^{1}$ Department of Accounting, Persian Gulf University, Bushehr, Iran \\ ${ }^{2}$ Department of Accounting, Payame Noor University, Bushehr, Iran
}

Email address:

safdar.alipour@pgu.ac.ir (S. Alipour)

*Corresponding author

\section{To cite this article:}

Safdar Alipour, Majid Gorgizadeh. Examining the Intellectual Capital Impact on the Profit Efficiency in Automobile and Parts Manufacturing Industry of Tehran Stock Exchange. Journal of Finance and Accounting. Vol. 5, No. 3, 2017, pp. 107-114. doi: $10.11648 /$ j.jfa.20170503.14

Received: April 3, 2017; Accepted: April 27, 2017; Published: May 25, 2017

\begin{abstract}
The objecdetive of this research is to study the impact of intellectual capital (IC) and its components on profit efficiency as a comprehensive criterion of financial performance. this research utilizes Pulic model in order to measure the IC of 23 companies in automobile and parts manufacturing industry of Tehran stock exchange for the period of 2011-2014. It also uses DEA technique and truncated regression in order to calculate profit efficiency and examine its relationship with IC respectively. the results indicated that human capital efficiency (HCE), capital employed efficiency (CEE), and value added intellectual capital (VAIC ${ }^{\mathrm{TM}}$ ) affect significantly and positively performance (profit efficiency) but Structural capital efficiency (SCE) is not associated significantly with performance. Among IC components, the human capital has the most impact on performance. Therefore, it can be asserted that, in automobile and parts industry, IC is capable of having effective role in financial decisions.
\end{abstract}

Keywords: Intellectual Capital, Data Envelopment Analysis (DEA), Profit Efficiency, Tehran Stock Exchange

\section{Introduction}

In the mid- $20^{\text {th }}$ century, financial economics attempted to pull attention towards company's new approach to business. This approach was based on the fundamental presumption that every organization has the capabilities, assets and other financial resources unique and distinct from other organizations and is a source of self-cured value and wealth creation. Therefore it is necessary to identify and measure all the resources and organizational capacity and balance sheet items [1].

Nowadays, the world's economy is evolving and this has led to a shift away from traditional forms of tangible economic drivers such as plant, machinery and real estate to an economy driven by the use of intangible resources such as knowledge. Intellectual capital is seen as an integral part of the workings of most modern organizations. The exploitation of this complex phenomenon can be the difference between the death and survival of an organization. It is therefore critical that a clear understanding of this concept exists within the managerial strata of any organization, with clear comprehension of the component elements of IC are and how it can be harnessed for the perusal of the organizational objectives [2].

The knowledge-based economic development is far more connected to practical application of human capital theory in which human capital becomes an intensive factor of development [3]. The new challenges of quota free global environment can be treated in the knowledge century via getting best out of enterprise's intellectual assets and recognizing corporate knowledge as being one of the most sustainable sources of competitive advantage in business. Shift from manufacturing era to knowledge economy requires maximizing value creation from corporate intellectual capital resources to succeed in competitive regime. In knowledge economy, IC is considered crucial for the competitiveness of companies regardless of the industry [4]. IC is a critical success factor for a company's success. 
Thus, firms' managers should focus on IC utilization to maximize long-run wealth [5].

Stewart [6] showed that IC means everything a business enterprise can employ it to increase its competitive advantage in marketplace and may include knowledge, information, rights to the intellectual properties, and experience. In other words, IC is an intangible asset creating value and could appear in financial statements as a marginal profit, but not as an accounting caption. Therefore, if a business enterprise can evaluate and analyze that intangible asset quantitatively, it will increase its competitiveness in industry.

In order to measure IC and help business enterprises to increase competitiveness ability, Pulic [7, 8] developed value added intellectual capital coefficient $\left(\mathrm{VAIC}^{\mathrm{TM}}\right.$ ) and many researchers such as Williams [9], Firer and Williams [10], Chen et al. [11], Tan et al. [12], Kamath [13], Ting \& Lean [14], Maditinos et al. [15], Chu et al. [16], Komnenic \& Pokrajcic [17], and Mehralian et al. [18] used this method in their work. Majority of the above-mentioned researches, subsequent to measuring IC, investigated its effects on financial ratios as the indication of performance. The problem requiring attention in this type of researches, especially in Maditinos et al. (2011), Komnenic \& Pokrajcic (2012), and Mehralian et al. (2012) is that in investigating the relationship between IC and performance, they considered different ratios as indicators of performance and therefore the obtained result is not comprehensive. In other word, in a typical research, for example, it is stated that IC or its components affect significantly income-to-capital ratio but, at the same time, do not affect income-to-assets ratio, making the results inconclusive. The cause of this problem can be sought in diversity of performance measurement criteria in these researches. Moving toward settlement of this problem, first it is necessary to convert different criteria of performance measurement into a single one and then investigate the relationship between IC and performance. Zou and Huan [19] in an attempt to solve this problem, first using DEA calculated a single criterion namely technical efficiency as an indication of performance and subsequently examined the IC effect on financial performance.

The current paper, concentrating on the previouslystated problem, first using DEA technique and considering information available in financial statements (especially income statement) of the companies belonging to the automobile and parts industry, calculates profit efficiency as a single and comprehensive measure of performance and then examines the effects of IC and its components on the performance. Based on the foregoing premise, the purpose and importance of this paper is summarized in highlighting the relationship between IC and financial performance of automobile and parts industry of Tehran stock exchange in order to provide managers of these companies with required incentives necessary for increasingly use of IC.

\section{Literature Review}

There is a large number of researchers examined IC effect on performance. For instance, it can be referred to RiahiBelkaoui [20] studied IC effect on performance among American multinational companies. He concluded that there is a significant positive relationship between IC and multinational companies' performance. Kujansivu and Lonnqvist [21] also found that there is a linear significant relationship between investments in IC, value of IC, and efficiency of IC on the one hand and ROA on the other.

In Turkey, Yalama \& Coskun [22] used DEA to answer the question of whether or not IC is an important factor in investers' decision-making. In fact, considering the same output variables and by changing input variables (among which IC was one of them), they came to select portfolio. The authors with the aim of examining IC effect on investors' decision-making, compared the returns on portfolios with respect to three different input varibles. The results revealed when input variable was IC, the selected portfolio had highest return in comparison with other situations. In other word, they demonstrated that information regarding IC can affect investors' decision-making. Zou and Huan (2011) also using DEA technique and financial information, especially financial ratios, firstly measure efficiency of sample business enterprises as an indication of financial performance and then tested the contribution of IC to the performance. The result showed a negative relationship between capital employed and structural capital on the one hand and efficiency on the other hand and a positive one between human capital and efficiency. However, the relationships between capital employed and human capital and efficiency were insignificant.

Tan et al. (2007) using Pulic model investigated the relationship between IC and its components and financial performance of companies listed in Singapore stock exchange. They concluded that there is a positive relationship between IC and its components and current performance. They also founded that IC affects significantly future performance of business enterprise and finally growth rate of IC relates positively to financial performance. Kamath (2008), through examining relationship between IC components and traditional financial performance measures including profitability, productivity, and market value among Indian firms, recognized that there is no any significant relationship between IC components and financial performance measures. however, in comparison to other IC components, human capital possesses strongest effect.

Ting \& Lean (2009) using Pulic model conducted an empirical study on the relationship between IC and financial performance among Malaysian companies and concluded that IC contributes to profitability significantly. The results also indicated that there is a significant relationship between IC components and profitability.

Maditinos et al. (2011) using data from 96 Greece companies, conducted an empirical investigation on the association between IC and companies' financial performance. The results revealed a significant relationship only between human capital and one of the financial performance measures (ROE). And there was no any relationship between IC and its other components and other financial performance measures 
(ROA and GR). The results also indicated that IC and its components didn't associate with market value. Komnenic and Pokrajcic (2012) analyzed the effects of IC components on ROA, ROE, and productivity (ATO) and obtained different results regarding effect of IC components on financial performance measures. They found a significantly positive correlation between human capital and employed capital on the one hand and ROA and ATO on the other hand but they didn't find any significant relationship between structural capital and these two financial performance measures. They also indicated that the IC threefold components affect ROE significantly and positively.

Joshi et al. [23] interestingly concluded that high levels of human and structural efficiencies do not necessarily lead to higher level of financial performance. As per the results of this study, physical capital determines ROA of the companies. HCE does not fully explain the variations in financial performance. Relatively smaller companies with high physical capital efficiency showed maximum financial performance. Overall, the obtained results highlight that IC performance has a complex relationship to the financial performance of Australian finance companies.

Makki and Lodhi (2014) in searching for finding a structural relationship among corporate governance, intellectual capital and financial performance indicated that corporate governance does not promote financial performance directly, but rather it enhances performance through utilizing intellectual capital resources. Precisely stated, a typical firm with good corporate governance measures, first improves intellectual capital efficiency and finally causes increase in return on investment, return on equity and net profit.

$\mathrm{Lu}$ et al. (2014) using data from Chinese life insurance industry and a slack-based dynamic DEA model, reached some evidences implying that company's operating efficiency can be improved through investing in human capital, structural capital and financial capital. Statistically, human capital is the most significant of the three proxies of IC.

In a more recent study, Nimtrakoon [24] using data of 213 technology firms listed on five ASEAN stock exchanges and a Modified Value Added Intellectual Coefficient (MVAIC) reported no significant difference in Modified Value Added Intellectual Coefficient (MVAIC) across five ASEAN countries; however, firms in each country tend to place a different degree of emphasis on components of MVAIC to generate corporate value. The results further indicate a positive relationship between IC and market value, confirming that firms with greater IC tend to have greater market value. Likewise, a positive relationship between IC and financial performance measures is confirmed. Specifically, IC is found to be positively associated with margin ratio and return on assets. Capital employed efficiency and human capital efficiency are found to be the most influential value drivers for both market value and financial performance while structural capital efficiency and relational capital efficiency possess less importance.

In a latest study, Nawaz and Haniffa [25] examine the effect of intangible resources, i.e intellectual capital (IC) on financial performance of 64 Islamic financial institutions (IFIs) operating in 18 different countries for the period 2007-2011 and indicate a significant positive relationship between VAIC and accounting performance based on return on assets (ROA). The results further indicate a significant positive relationship between accounting performance and capital employed efficiency (CEE) and human capital efficiency (HCE), but no significant relationship with regards to structural capital efficiency. Overall, the results suggest that value creation capability of IFIs is highly influenced by HCE and CEE.

Furthermore, in Iran, Mehralian et al. (2012) through examining the effect of IC on performance (profitability, productivity and market value) in pharmaceutical industry, concluded that IC affects profitability in a significant manner, but couldn't have any relationship with productivity and market value.

\section{Methodology}

The aim of this research is to investigate IC effect on profit efficiency in automobile and parts industry of Iran. Accordingly, it is necessary to measure IC of sample companies and analyze its effect on profit efficiency. In this research, Pulic model has been utilized to measure IC.

\subsection{Measuring IC}

Pulic (1998, 2000) developed the "Value Added Intellectual Coefficient" (VAIC ${ }^{\mathrm{TM}}$ ) to measure the IC of companies. He is concerned with two other important aspects of valuation and value creation yet unsolved by other methods:

(1) Market-based IC value cannot be calculated for companies that are not listed on the stock market. Such companies need an alternative way to determine their marketbased IC value.

(2) There is no adequate system of monitoring the efficiency of current business activities performed by employees, or whether their potential is directed towards value creation or value destruction.

The VAIC ${ }^{\mathrm{TM}}$ method is designed to provide information about the value creation efficiency of tangible and intangible assets within a company. The model starts with a company's ability to create value added (VA). VA is the difference between sales (OUT) and inputs (IN) and is represented by the model 1:

$$
\mathrm{VA}=\mathrm{OUT}-\mathrm{IN}
$$

OUT includes revenues from sale of merchandises and services and IN encompasses all costs incurring in generating that revenues except for salaries and wages of employees. Notice that in calculating value added, salaries and wages expenses are ignored. In other word, due to active role of employees in value creation process, intellectual capital potential (represented by salary and wage expenses) is not considered as expense. Consequently, a key aspect of Pulic model is to respect employees as a value creator component 
in business enterprise. The next phase in calculating Value Added Intellectual Coefficient $\left(\mathrm{VAIC}^{\mathrm{TM}}\right.$ ) is to calculate human capital efficiency with respect to creating value for business enterprise. Model 2 illustrates how to calculate human capital efficiency (HCE):

$$
\mathrm{HCE}=\frac{\mathrm{VA}}{\mathrm{HC}}
$$

In this equation, $\mathrm{HCE}, \mathrm{VA}$, and $\mathrm{HC}$ are human capital efficiency coefficient, value added, and total salary and wage expenses of employees respectively.

The third stage includes calculation of structural capital efficiency (SCE) in which structural capital (SC) is divided by value added (VA) as demonstrated in model 4. (SC) is also calculated through model 3 . SCE is more strictly defined as structural capital efficiency in creating value added.

$$
\begin{gathered}
\mathrm{SC}=\mathrm{VA}-\mathrm{HC} \\
\mathrm{SCE}=\frac{\mathrm{SC}}{\mathrm{VA}}
\end{gathered}
$$

The fourth stage in measuring and evaluating IC, is to calculate capital employed efficiency (CEE). CEE can be calculated using model 5 in which abbreviations CEE and CE are capital employed efficiency and capital employed, including book value of net assets, respectively.

$$
\mathrm{CEE}=\frac{\mathrm{VA}}{\mathrm{CE}}
$$

Finally, the $\mathrm{VAIC}^{\mathrm{TM}}$ is the total of HCE, SCE, and CEE which illustrated in the following equation as model 6 :

$$
\mathrm{VACI}^{\mathrm{TM}}=\mathrm{HCE}+\mathrm{SCE}+\mathrm{CEE}
$$

After measuring IC, it is necessary to calculate profit efficiency of sample companies. In this research, as mentioned earlier, DEA technique has been utilized in order to measure profit efficiency. The following section describes how to calculate profit efficiency by using this technique.

\subsection{Non-parametric Techniques in Profit Efficiency Estimation}

Most literature relating to efficiency measurements has based its analysis either on parametric or non- parametric methods. The choice of estimation technique has attracted debate since no method is strictly preferable over one [26]. This paper uses the non-parametric DEA-based technique to analyze profit efficiency of Iranian companies due to the following reasons. DEA is a linear programming-based technique proposed by Charnes et al. [27] (1978), which can be used to determine the efficiency of a group of decisionmaking units (DMUs) relative to an envelope (efficient frontier) by optimally weighting inputs and outputs. Additionally, DEA provides a single indicator of efficiency irrespective of the number of inputs and outputs. DEA has been applied in a number of fields, including education institution, healthcare, banking and high-tech manufacturing. A number of studies have used DEA as an evaluation technique, some of them have evaluated the efficiency of high-technology firms from various perspectives, including manpower (Reitsperger et al [28]; Thore et al. [29]; Cooper et al. [30]; Despotis [31]), cost (Kozmetsky and Yue [32]; Kauffmann et al. [33]), technology (Linton and Cook [34]; SubbaNarasimha et al. [35]), R\&D (Oral et al. [36]; Linton et al. [37]; Verma and Sinha [38]) and profits (Shao and Lin [39]; Verma and Sinha, 2002; Ariff and Can [40]; Das and Ghosh [41]).

The most important advantage of DEA, is the capability of comparison between several DMUs with respect to the several criteria. Among other advantages of this nonparametric technique over the parametric methods, we can point to the nonnecessity of the functional form estimation. Using all of the existing information is another advantage of this method while the parametric methods lack this capability and analyze the data in a sample (Halkos and Salamouris [42])

Considering above-mentioned advantages relating to DEA, simplicity of using this method in measuring efficiency and also widespread use of it in previous studies such as Isik and Hassan [43], Ariff and Can (2008), Das and Ghosh (2009), and Ray and Das [44], this paper employ this method in order to measure profit efficiency of DMUs.

Flowing a debate advocating DEA implementation presented in the previous paragraphs, In this section we present a model for calculating cost and revenue efficiency, the model developed by Färe and Grosskopf [45], Färe et al. [46].

\subsubsection{Profit efficiency (PE)}

To illustrate the non-parametric methodology for calculating profit efficiency, let us suppose that there exist $\mathrm{N}$ firms $(\mathrm{i}=1, \ldots, \mathrm{N})$ that produce a vector of $\mathrm{q}$ outputs $\mathrm{yi}=(\mathrm{yi} 1, \ldots, \mathrm{yiq}) \in \mathrm{Rq}++$ that they sell at prices $\mathrm{ri}=(\mathrm{ri} 1, \ldots, \mathrm{riq})$ $\in \mathrm{Rq}++$ using a vector of $\mathrm{p}$ inputs $\mathrm{xi}=(\mathrm{xi} 1, \ldots, \mathrm{xip}) \in \mathrm{Rp}++$ for which they pay prices $\mathrm{wi}=($ wil,$\ldots$, wip) $\in \mathrm{Rp}++$. The profit efficiency for the case of firm $\mathrm{j}$ can be calculated by solving the following problem of linear programming (model 7) proposed by Färe and Grosskopf (1997), Färe et al. (2004):

$$
\begin{gathered}
\operatorname{Max} \sum_{\mathrm{q}} \mathrm{r}_{\mathrm{j}} \mathrm{y}_{\mathrm{jq}}-\sum_{\mathrm{p}} \mathrm{w}_{\mathrm{jp}} \mathrm{x}_{\mathrm{jp}} \\
\text { s.t. } \sum_{\mathrm{i}} \lambda_{\mathrm{i}} \mathrm{y}_{\mathrm{iq}} \geq \mathrm{y}_{\mathrm{jq}} \forall \mathrm{q} \\
\sum_{\mathrm{i}} \lambda_{\mathrm{i}} \mathrm{x}_{\mathrm{ip}} \leq \mathrm{x}_{\mathrm{jp}} \forall \mathrm{p} \\
\sum_{\mathrm{i}} \lambda_{\mathrm{i}}=1 ; \lambda_{\mathrm{i}} \geq 0 ; \mathrm{i}=1, \ldots, \mathrm{N}
\end{gathered}
$$

The solution to which corresponds to the vector of outputs $y^{*} j=(y * j 1, \ldots, y * j q)$ and the input demand vector $x^{*} j=(x * j 1, \ldots, x * j p)$ which maximise the profits with the given prices of outputs (r) and of inputs (w). This solution is obtained from a linear combination of firms that produces at least as much of each of the outputs using the 
same or less amount of inputs. If this hypothetical firm were subject to the same input and output prices as those faced by firm $j$ it would have a profit $P * j=\Sigma r q j \cdot y * q j-$ $\Sigma w p j \cdot x^{*}$ pj which, by definition, will be higher than or equal to that of firm $\mathrm{j} P \mathrm{Pj}=\Sigma \mathrm{rqj} \cdot \mathrm{yqj}-\Sigma w p j \cdot \mathrm{xpj}$. Having solved the model 7 , standard profit efficiency (SPEj) is then calculated as (model 8):

$$
P E_{j}=\frac{\sum_{q} r_{j} y_{j q}-\sum_{p} w_{j p} x_{j p}}{\sum_{q} r_{j} y_{i q}^{*}-\sum_{p} w_{j p} x_{i p}^{*}}
$$

Where PEj represents the ratio between the observed profits $(\mathrm{Pj})$ and the maximum profits $(\mathrm{SP} * \mathrm{j})$ associated with the production of the output vector $\mathrm{y}^{* \mathrm{j}}$ and with demand for inputs $x * j$ which maximise profits for firm $j$.

It can be inferred from model 8 that if a DMU has a loss, The efficiency score will be negative. Therefore, it can be concluded that the efficiency score might be between 1 and $\infty$.

Following the calculation of IC and profit efficiency, the IC effect on profit efficiency must be evaluated. In this research, in order to evaluate the effect, regression methods have been used in which dependent variable is profit efficiency. Since dependent variable (profit efficiency calculated using DEA) could have a value ranging from $-\infty$ to 1 , truncated regression as well as panel data is necessarily used as it is used in Sueyoshi et al. [47], Bruce [48], and
Wang et al. [49]. Before dealing with empirical results, research variables are introduced as follow.

\subsection{Variables and Sample Used}

The sample consists of 23 companies among those listed in Tehran Stock Exchange. In order to increase reliability and comparability, all of the companies have been selected among a same industry namely automobile and parts Production industry for a four-year period (2011-2014). Considering the objectives of this research, that are measuring profit efficiency and investigating its relationship to the IC and its components of the DMUs, this research variables have been categorized into two groups identical to Mahdavi et al. [50]: the first group consists of input and output variables of DMUs aiming at the measurement of profit efficiency that are summarized in Table 1. The second group also consists of independent variables including intellectual capital, human capital, structure capital, and employed capital used to determine the relationship of them to profit efficiency as dependent variable. Moreover, other two variables including financial leverage and natural logarithm of stock price at the end of the period are taken into account as control variables. Table 2 presents how the independent and control variables used in the second stage of research are calculated:

Table 1. Variables used in the profit efficiency estimation: means and standard deviations for 2011-2014 (standard deviations in parentheses).

\begin{tabular}{|c|c|c|c|c|c|}
\hline Symbol & Definition & 2011 & 2012 & 2013 & 2014 \\
\hline $\mathrm{x}_{1}$ & Number of employees & $\begin{array}{l}2899.70 \\
(6058.67)\end{array}$ & $\begin{array}{l}3044.13 \\
(6263.31)\end{array}$ & $\begin{array}{l}3097.39 \\
(6439.13)\end{array}$ & $\begin{array}{l}3100.65 \\
(6531.77)\end{array}$ \\
\hline $\mathrm{x}_{2}$ & Physical capital=book value of fixed assets & $\begin{array}{l}823058.96 \\
(1882965.43)\end{array}$ & $\begin{array}{l}903829.22 \\
(2117360.67)\end{array}$ & $\begin{array}{l}956010.35 \\
(2319028.48)\end{array}$ & $\begin{array}{l}973818.3 \\
(2621617.15)\end{array}$ \\
\hline $\mathrm{y}$ & Cost of goods sold (COGS) & $\begin{array}{l}2646408 \\
(5934633.58)\end{array}$ & $\begin{array}{l}3062599.48 \\
(7527125.12)\end{array}$ & $\begin{array}{l}3392643.04 \\
(8338301.14)\end{array}$ & $\begin{array}{l}4216403.26 \\
(10145067.35)\end{array}$ \\
\hline $\mathrm{w}_{1}$ & Price of labour=personnel expenses/ x1 & $\begin{array}{l}80.76 \\
(20.15)\end{array}$ & $\begin{array}{l}91.79 \\
(21.13)\end{array}$ & $\begin{array}{l}114.44 \\
(30.69)\end{array}$ & $\begin{array}{l}139.99 \\
(41.50)\end{array}$ \\
\hline & Price of physical capital $=$ other operating expenses include & 3.24 & 3.34 & 3.81 & 5.03 \\
\hline $\mathrm{w}_{2}$ & $\begin{array}{l}\text { direct material cost, overhead cost and selling, general and } \\
\text { administrative expenses (except for labour cost)/x2 }\end{array}$ & $(1.53)$ & $(1.6)$ & $(1.81)$ & $(3.17)$ \\
\hline $\mathrm{r}$ & Price of COGS $=$ operating revenues $/ y$ & $\begin{array}{l}1.29 \\
(0.12)\end{array}$ & $\begin{array}{l}1.3 \\
(0.13)\end{array}$ & $\begin{array}{l}1.27 \\
(0.12)\end{array}$ & $\begin{array}{l}1.21 \\
(0.09)\end{array}$ \\
\hline $\mathrm{C}$ & Total costs $=$ operating costs & $\begin{array}{l}2832941.78 \\
(6372572.83)\end{array}$ & $\begin{array}{l}3306140.4 \\
(8150349.01)\end{array}$ & $\begin{array}{l}3702482.5 \\
(9100162.38)\end{array}$ & $\begin{array}{l}4534878.96 \\
(11010347.6)\end{array}$ \\
\hline
\end{tabular}

Table 2. Description of truncated regression variables: means and standard deviations for 2011-2014 (standard deviations in parentheses).

\begin{tabular}{|c|c|c|c|c|c|}
\hline Name \& Symbol & Definition & 2011 & 2012 & 2013 & 2014 \\
\hline Intellectual Capital Value Added (VAIC ${ }^{\mathrm{TM}}$ ) & Model 6 & $\begin{array}{l}3.96 \\
(0.98)\end{array}$ & $\begin{array}{l}3.65 \\
(1.01)\end{array}$ & $\begin{array}{l}3.58 \\
(1.19)\end{array}$ & $\begin{array}{l}2.89 \\
(1.77)\end{array}$ \\
\hline Human Capital Efficiency (HCE) & Model 2 & $\begin{array}{l}2.46 \\
(0.9)\end{array}$ & $\begin{array}{l}2.15 \\
(0.83)\end{array}$ & $\begin{array}{l}1.99 \\
(0.65)\end{array}$ & $\begin{array}{l}1.84 \\
(0.78)\end{array}$ \\
\hline Structure Capital Efficiency (SCE) & Model 4 & $\begin{array}{l}0.54 \\
(0.15)\end{array}$ & $\begin{array}{l}0.48 \\
(0.15)\end{array}$ & $\begin{array}{l}0.45 \\
(0.16)\end{array}$ & $\begin{array}{l}0.35 \\
(0.31)\end{array}$ \\
\hline Capital Employed Efficiency (CEE) & Model 5 & $\begin{array}{l}0.95 \\
(0.42)\end{array}$ & $\begin{array}{l}1.02 \\
(0.83)\end{array}$ & $\begin{array}{l}1.13 \\
(1.09)\end{array}$ & $\begin{array}{l}0.7 \\
(1.09)\end{array}$ \\
\hline Financial Leverage (FL) & Total debt/total asset & $\begin{array}{l}0.66 \\
(0.12)\end{array}$ & $\begin{array}{l}0.68 \\
(0.14)\end{array}$ & $\begin{array}{l}0.69 \\
(0.12)\end{array}$ & $\begin{array}{l}0.7 \\
(0.14)\end{array}$ \\
\hline Price Natural Logarithm (PNL) & $\operatorname{Ln}$ (price) & $\begin{array}{l}7.67 \\
(0.62)\end{array}$ & $\begin{array}{l}7.46 \\
(0.64)\end{array}$ & $\begin{array}{l}7.24 \\
(0.69)\end{array}$ & $\begin{array}{l}7.22 \\
(0.53)\end{array}$ \\
\hline
\end{tabular}




\section{Empirical Results}

\subsection{First Stage: Analysis of the Profit Efficiency Estimates}

This section is devoted to the calculation of profit efficiency using DEA. Considering previously-presented variables in Table 1, as well as model 7 and 8 and also using DEA Frontier, the efficiency scores of 23 companies have been calculated and presented in Table 3 . The bottom line of the Table makes obvious that the average efficiency of DMUs in earning profit is $39 \%$. In other word, These DMUs are $61 \%$ inefficient in achieving profit.

Table 3. Profit efficiency scores

\begin{tabular}{llllll}
\hline \multicolumn{7}{c}{ Profit Efficiency } & & & \\
\hline & $\mathbf{2 0 1 1}$ & $\mathbf{2 0 1 2}$ & $\mathbf{2 0 1 3}$ & $\mathbf{2 0 1 4}$ & Mean \\
\hline DMU1 & 1.00 & 1.00 & 0.22 & 0.02 & 0.56 \\
DMU2 & 1.00 & 1.00 & 0.64 & 0.17 & 0.70 \\
DMU3 & 0.33 & 0.42 & 0.02 & -0.03 & 0.18 \\
DMU4 & 0.11 & 0.14 & 0.15 & 0.13 & 0.13 \\
DMU5 & 0.29 & 0.38 & 0.06 & 0.06 & 0.20 \\
DMU6 & 0.09 & 0.14 & 0.04 & 1.00 & 0.32 \\
DMU7 & 0.11 & 0.07 & 0.04 & 0.02 & 0.06 \\
DMU8 & 0.04 & 0.05 & 0.04 & 0.04 & 0.04 \\
DMU9 & 0.37 & 1.00 & 0.26 & 0.22 & 0.46 \\
DMU10 & 1.00 & 1.00 & 1.00 & 1.00 & 1.00 \\
\hline
\end{tabular}

\begin{tabular}{llllll}
\hline \multicolumn{7}{l}{ Profit Efficiency } & & & \\
\hline & $\mathbf{2 0 1 1}$ & $\mathbf{2 0 1 2}$ & $\mathbf{2 0 1 3}$ & $\mathbf{2 0 1 4}$ & Mean \\
\hline DMU11 & 1.00 & 1.00 & 1.00 & 1.00 & 1.00 \\
DMU12 & 1.00 & 1.00 & 1.00 & 1.00 & 1.00 \\
DMU13 & 0.11 & 1.00 & 0.04 & 0.04 & 0.30 \\
DMU14 & 0.11 & 0.09 & 0.04 & 0.00 & 0.06 \\
DMU15 & 0.05 & 0.05 & 0.10 & 0.14 & 0.09 \\
DMU16 & 0.22 & 0.19 & 0.09 & 0.10 & 0.15 \\
DMU17 & 0.16 & 0.11 & 0.15 & 0.17 & 0.15 \\
DMU18 & 1.00 & 1.00 & 0.10 & -0.13 & 0.49 \\
DMU19 & 0.22 & 1.00 & 1.00 & 1.00 & 0.81 \\
DMU20 & 1.00 & 1.00 & 1.00 & 1.00 & 1.00 \\
DMU21 & 0.08 & 0.07 & 0.03 & 0.01 & 0.05 \\
DMU22 & 0.34 & 0.53 & 0.13 & 0.02 & 0.25 \\
DMU23 & 0.08 & 0.10 & 0.04 & 0.04 & 0.06 \\
Mean & 0.42 & 0.54 & 0.31 & 0.31 & 0.39 \\
S. D & 0.40 & 0.43 & 0.39 & 0.43 & 0.35 \\
\hline
\end{tabular}

Figure 1 illustrates average trend of profit efficiency relating to the DMUs. This Figure as well as Table 3 indicates that DMUs 10, 11, 12, and 20 during the studied period have the relative efficiency of $100 \%$. Therefore, these DMUs could be considered as reference units for inefficient units. In fact, inefficient units, taking into consideration these units as successful patterns, can change their inputs and outputs in such a way that approach efficiency frontier.

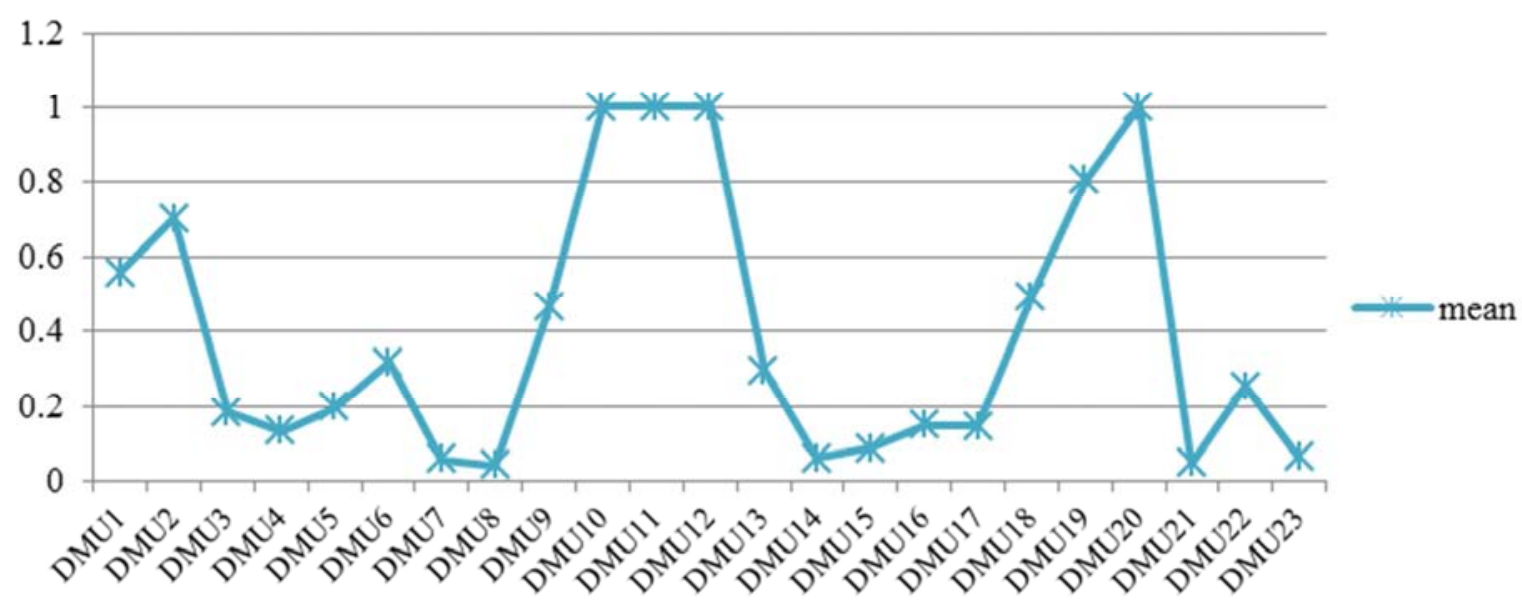

Figure 1. Profit efficiency.

\subsection{Second Stage: Analyzing the Effect of IC and Its Components on Profit Efficiency Calculated at the First Stage}

After calculating profit efficiency, now it is aimed to investigate the effect of IC and its components on performance (previously-calculated profit efficiency). It is stated earlier that in this research, truncated regression has been utilized aiming at examining this effect. Following this objective, considering the profit efficiency as dependent variable and the variables presented in Table 2 as independent and control variables, the truncated regression model has been estimated and depicted in Tables 4 and 5 .

The results presented in Table 4 suggests that human capital efficiency (HCE) and capital employed efficiency
(CEE) affect profit efficiency in a significant and positive manner, however, structural capital efficiency (SCE) couldn't have any significant correlation with profit efficiency of studied companies. It is also inferred from Table 5 that value added intellectual capital $\left(\mathrm{VAIC}^{\mathrm{TM}}\right.$ ) contributes significantly to the profit efficiency of studied sample.

Table 4. The results arising from truncated regression (HCE, SCE, and CEE as independent variables and FL and PNL as control variables).

\begin{tabular}{llll}
\hline & Coefficient & Z-Statistic & \\
\hline C & -0.534 & -3.508 & 0 \\
HCE & 0.087 & 2.414 & 0.016 \\
SCE & -0.026 & -0.208 & 0.835 \\
CEE & 0.034 & 2.354 & 0.018 \\
FL & 0.059 & 0.525 & 0.599 \\
PNL & 0.057 & 2.78 & 0.005 \\
\hline
\end{tabular}


Table 5. The results arising from truncated regression (VAIV ${ }^{T M}$ as independent variable and FL and PNL as control variables).

\begin{tabular}{llll}
\hline & Coefficient & Z-Statistic & \\
\hline C & -0.593 & -4.029 & 0 \\
VAIC $^{\text {TM }}$ & 0.048 & 4.146 & 0 \\
FL & 0.083 & 0.938 & 0.348 \\
PNL & 0.066 & 3.379 & 0.001 \\
\hline
\end{tabular}

\section{Discussion and Conclusion}

In this research, in a new way, the effect of IC and its components on business performance have been investigated. The current paper, rather than taking into account all criteria of ROA, ROE, productivity, and so on in evaluating IC effect (Maditinos et al. (2011), Komnenic \& Pokrajcic (2012), and Mehralian et al. (2012)), attempted to attain a single measure as the financial performance measure using DEA. In fact, in this research, utilizing information relating to operational section of income statement and fixed assets of balance sheet, that have clues for business performance and have high comparability among companies from a same industry, the profit efficiency as a single and comprehensive measure has been calculated. Afterwards, using truncated regression, the effect of IC and its components on profit efficiency is analyzed.

The results are in accordance with the most of studies already done on the IC effect on performance. Indeed, it is evidenced that $\mathrm{HCE}, \mathrm{CEE}$ and $\mathrm{VAIC}^{\mathrm{TM}}$ affect performance (profit efficiency) significantly and positively. However, SCE has no any significant relationship with performance. Among them, human capital has the most effect on performance. Therefore, it can be concluded that, in automobile and parts industry, IC does have an important role in financial decisions. In fact, managers, owners and investors should not relinquish taking into account the IC effective role in performance. Additionally, information relating to this asset dose not disclose completely in balance sheet. Overall, the current research came to an end concluding that information pertaining to IC can have vital importance in financial decisions. Investors and other financial information users should pay attention to this fact that information regarding IC is not an available and ready-for-use figure, but nevertheless it is necessary to devote a significant respect to this everincreasing important factor. In fact, decision-makers and users have no other alternative except estimating and incorporating IC into their decisions, unless there is a clear and appropriate framework for measuring and disclosing IC.

\section{References}

[1] Jafari, E. (2013), “intellectual capital and its effects on firm's market value and financial performance in Iran: an investigating pulic model", research journal of recent sciences, Vol. 2, No. 3, pp. 1-6.

[2] Henry, L., (2013), "Intellectual capital in a recession: evidence from UK SMEs", Journal of Intellectual Capital, Vol. 14, Iss. 1, pp. $84-101$.

[3] Hajrullina, A. D. and Romadanova, O. A. (2014), "technique of measurement of value of the human capital as intangible asset of corporation", life science journal, Vol. 11, No. 16, pp. 518-521.

[4] Makki, M. A. M. and Lodhi, S. A. (2014), "impact of corporate governance on intellectual capital efficiency and financial performance", Pakistan journal of commerce and social sciences, Vol. 8, No. 2, pp. 305-330.

[5] Lu, W. M., Wang, W. K. and Kweh, Q. L. (2014), intellectual capital and performance in the Chinese life insurance industry, omega, Vol. 42, pp. 65-74.

[6] Stewart, T. A. (1997), Intellectual capital, Nicholas Brealey Publishing, London.

[7] Pulic, A. (1998), "Measuring the performance of intellectual potential in knowledge economy", available at: www.measuring-ip.at/OPapers/Pulic/Vaictxt/vaictxt.html

[8] Pulic, A. (2000), "VAICTM-an accounting tool for IC management", available at: www. measuringip.at/Papers/ham99txt.htm

[9] Williams, M. (2001), "Are intellectual capital performance and disclosure practice related?", Journal of Intellectual Capital, Vol. 2 No. 3, pp 192-203.

[10] Firer, S. and Williams, S. M. (2003), "Intellectual capital and traditional measures of corporate performance", Journal of Intellectual Capital, Vol. 4 No. 3, pp. 348-60.

[11] Chen, M. C., Cheng, S. J. and Hwang, Y. (2005), “An empirical investigation of the relationship between intellectual capital and firms' market value and financial performance", Journal of Intellectual Capita, Vol. 6 No. 2, pp. 159-76.

[12] Tan, H. P., Plowman, D. and Hancock, P. (2007), "Intellectual capital and financial returns of companies", Journal of Intellectual Capital, Vol. 8 No. 1, pp 76-95.

[13] Kamath, G. B. (2008), "Intellectual capital and corporate performance in Indian pharmaceutical industry", Journal of Intellectual Capital, Vol. 9 No. 4, pp. 684-704.

[14] Ting, I. W. K. and Lean, H. H. (2009), "Intellectual capital performance of financial institutions in Malaysia", Journal of Intellectual Capital, Vol. 10 No. 4, pp 588-99.

[15] Maditinos, D., Chatzoudes, C., Tsairidis, C. and Theriou, G. (2011), "The impact of intellectual capital on firms' market value and financial performance", Journal of Intellectual Capital, Vol. 12 No. 1, pp. 132-51.

[16] Chu, S. K. W., Chan, K. H., Yu, K. Y., Ng, H. T. and Wong, W. K. (2011), "An Empirical Study of the Impact of Intellectual Capital on Business Performance", Journal of Information \& Knowledge Management, Vol. 10 No. 1, pp. $11-21$

[17] Komnenic, B. and Pokrajcic, D. (2012), "Intellectual capital and corporate performance of MNCs in Serbia", Journal of Intellectual Capital, Vol. 13 No. 1, pp. 106-19.

[18] Mehralian, GH., Rajabzadeh, A., Sadeh, M. R. and Rasekh, H. R. (2012), "Intellectual capital and corporate performance in Iranian pharmaceutical industry", Journal of Intellectual Capital, Vol. 13 No. 1, pp. 138- 58.

[19] Zou, X. and Huan, T-C. (2011), "A study of the intellectual capital's impact on listed banks' performance in China" African Journal of Business Management, Vol. 5 No. 12, pp 5001-9. 
[20] Riahi-Belkaoui, A. (2003), "Intellectual capital and firm performance of US multinational firms A study of the resource-based and stakeholder views", Journal of Intellectual Capital, Vol. 4 No. 2, pp 215- 26.

[21] Kujansivu, P. and Lonnqvist, A. (2005), "How do investments in intellectual capital create profits?", Frontiers of E-business Research, Vol. 4 No. 3, pp. 256-75.

[22] Yalama, A., and Coskun, M. (2007), "Intellectual capital performance of quoted banks on the Istanbul stock exchange market”, Journal of Intellectual Capital, Vol. 8 No. 2, pp 25671 .

[23] Joshi, M., Cahill, D., Sidhu, J. and Kansal, M. (2013), "Intellectual capital and financial performance: an evaluation of the Australian financial sector", Journal of intellectual capital, vol. 14, no. 2, pp. 264-285.

[24] Nimtrakoon, S. (2015),"The relationship between intellectual capital, firms' market value and financial performance", Journal of Intellectual Capital, Vol. 16 Iss 3 pp. $587-618$

[25] Nawaz, T. and Haniffa, R. (2017) "Determinants of financial performance of Islamic banks: an intellectual capital perspective", Journal of Islamic Accounting and Business Research, Vol. 8 Issue: 2, pp.130-142.

[26] Murillo-Zamorano, L. R. (2004), "Economic efficiency and frontier techniques", Journal of Economic Surveys, Vol. 18 No. 1, pp. 33- 77.

[27] Charnes, A., Cooper, W. W. and Rhodes, E. (1978), "Measuring the efficiency of decision making units", European Journal of Operational Research, Vol. 2 No. 6, pp. 429-44.

[28] Reitsperger, W. D., Daniel, S. J., Tallman, S. B. and Chismar, W. G. (1993), "Product quality and cost leadership: compatible strategies?", Management International Review, Vol. 33 No. 1, pp 7- 21.

[29] Thore, S., Phillips, F., Ruefli, T. W. and Yue, P. (1996), "DEA and the management of the product cycle: the U. S. Computer industry", Computers and Operations Research, Vol. 23 No. 4, pp 341-56.

[30] Cooper, W. W., Park, K. S. and Yu, G. (2001), “An illustrative application of idea (imprecise data envelopment analysis) to a Korean mobile telecommunication company", Operations Research, Vol. 49 No. 6, pp. 807-20.

[31] Despotis, D. K. (2005), "Measuring human development via data envelopment analysis: the case of Asia and the pacific", Omega, Vol. 33 No. 5, pp. 385-90.

[32] Kozmetsky, G. and Yue, P. (1998), "Comparative Performance of Global Semiconductor Companies", Omega, Vol. 26 No. 2, pp. 153-75.

[33] Kauffmann, P. J., Unal, R., Fernandez, A. A. and Keating, C. B. (2000), "A Model for Allocating Resources to Research Programs by Evaluating Technical Importance and Research Productivity", Engineering Management Journal, Vol. 12 No. 1, pp. 5-8.

[34] Linton, J. D. and Cook, W. D. (1998), "Technology implementation: a comparative study of Canadian and U. S. Factories", INFOR, Vol. 36 No. 3, pp. 142-50.
[35] SubbaNarasimha, P. N., Ahmad, S. and Mallya, S. N. (2003), "Technological knowledge and firm performance of pharmaceutical firms", Journal of Intellectual Capital, Vol. 4 No. 1, pp 20-33.

[36] Oral, M., Kettani, O. and Lang, P. (1991), "A methodology for collective evaluation and selection of industrial $\mathrm{R}$ and $\mathrm{D}$ projects", Management Science, Vol. 37 No. 7, pp. 871- 85.

[37] Linton, J. D., Walsh, S. T. and Morabito, J. (2002), "Analysis, ranking and selection of $\mathrm{R}$ and $\mathrm{D}$ projects in a portfolio", R\&D Management, Vol. 32 No. 2, pp. 139-48.

[38] Verma, D. and Sinha, K. K. (2002), "Toward a theory of project interdependencies in high tech R\&D environments", Journal of Operations Management, Vol. 20 No. 5, pp 451-68.

[39] Shao, B. B. M. and Lin, T. L. (2002), “Technical efficiency analysis of Information technology investments: a two-stage empirical investigation" Information \& Management, Vol. 39 No. 5, pp 391-401.

[40] Ariff, M. and Can, L. (2008), "Cost and profit efficiency of Chinese banks: A non-parametric analysis", China Economic Review, Vol. 19 No. 2, pp. 260-73.

[41] Das, A. and Ghosh, S. (2009), "Financial Deregulation and Profit Efficiency: A Non-parametric Analysis of Indian Banks", MPRA, 1-21.

[42] Halkos, G. E. and Salamouris, D. S. (2004), "Efficiency Measurement of the Greek Commercial Banks with the Use of Financial Ratios: a Data Envelopment Analysis Approach", Management Accounting Research, Vol. 15 No. 2, pp. 201-24.

[43] Isik, I. and Hassan, M. K. (2002), "Cost and Profit Efficiency of the Turkish Banking Industry: An Empirical Investigation", Financial Review, Vol. 37 No. 2, pp. 257-80.

[44] Ray, S. C. and Das, A. (2010), "Distribution of cost and profit efficiency: Evidence from Indian banking", European Journal of Operational Research, Vol. 201 No. 1, pp. 297- 307.

[45] Färe, R. and Grosskopf, S. (1997), "Profit efficiency, Farrell decomposition and the Mahler inequality", Economic Letters, Vol. 57 No. 3, pp. 283-87.

[46] Färe, R., Grosskopf, S. and Weber, W. (2004), "The effect of risk-based capital requirements of profit efficiency in banking", Applied Economics, Vol. 36 No. 15, pp. 1731-43.

[47] Sueyoshi, T., Goto, M. and Omi, Y. (2010), "Corporate governance and firm performance: Evidence from Japanese manufacturing industries after the lost decade", European Journal of Operational Research, Vol. 203 No. 3, pp 724-36.

[48] Bruce, D. N. (2011), "Corporate Governance Mechanisms and Firm Efficiency", International Journal of Business and Management, Vol. 6 No. 5, pp. 28-41.

[49] Wang, W. K., Lu, W. M. and Lin, Y. L. (2012), "Does corporate governance play an important role in BHC performance? Evidence from the U.S.”, Economic Modelling, Vol. 29 No. 3, pp 751-60.

[50] Mahdavi, GH., Ghayouri Moghaddam, A. and Alipour, S. (2012), "An investigation of cost, revenue and profit efficiency: The case of Iranian companies", African Journal of Business Management, Vol. 6, No. 30, pp. 8879-8888. 